\title{
SELEKSI JENIS ANTIOKSIDAN DAN PENENTUAN KONSENTRASI OP'TIMUMINYA PADA PEMURNIAN MINYAK IKAN LEMURU
}

\author{
Hari Eko Irianto"), Yusro Nuri Fawzya ${ }^{*}$ dan Rosmawaty Peranginangin ${ }^{*}$ )
}

\begin{abstract}
ABSTRAK
Minyak ikan mengandung asam lemak tak jenuh cukup tinggi, sehingga menyebabkan mudah rusak akibat oksidasi. Penelitian ini ditujukan untuk mendapatkan metoda peningkatan stabilitas minyak ikan selama pemurnian dengan menggunakan antioksidan. Jenis antioksidan yang diteliti efektivitasnya pada penelitian pendahuluan adalah BHA, BHT, propil galat, TBHQ dan tokoferol. Antioksidan yang paling efektif diteruskan pada penelitian lanjutan, yaitu untuk menentukan konsentrasi yang paling optimum. Konsentrasi yang diteliti adalah 0, 50, 100, 150 dan 200 ppm. Minyak hasil pemurnian diamati stabilitasnya dengan menggunakan Scbaal Oven Method.
\end{abstract}

Hasil penelitian menunjukkan bahwa TBHQ adalah antioksidan yang paling efektif digunakan pada pemurnian minyak ikan lemuru, yaitu dengan menghasilkan minyak murni yang mempunyai bilangan peroksida dan TBA terendah. Sedangkan konsentrasi TBHQ optimum yang dapat ditambahkan untuk mengurangi proses oksidasi selama pemurnian adalah $50 \mathrm{ppm}$. Untuk mendapatkan stabilitas yang baik selama penyimpanan, minyak yang telah dimurnikan perlu ditambah antioksidan lagi.

\section{ABSTRACT: Selection of Antioxidants Aad Determination of Its Optimum Concentration Used in the Refining of Sardine Oil, by: Hari Ebo Irianto, Yusro Nuri Fawzya dan Rosmawaty Peranginangin.}

Fish oil contains high polyunsaturated fatty acids, consequently fish oil easily deteriorates due to oxidation. This study was aimed to find a method for the stability improvement of fish oil during refining through antioxidant addition. Antioxidants determined their effectiveness in the preliminary experiment were BHA, BHT, propyl gallate, TBHQ and tocopherol. The most effective antioxidant was continued into the main experiment to determine the most optimum concentration to be used. The concentration levels investigated were $0,50,100,150$ and 200 ppm. Refined oil was investigated its stability using Schaal Oven Method.

Results showed that TBHQ was the most effective antioxidant to be used in the fish oil refining, in which the refined fish oil produced had the lowest peroxide and TBA values. The optimum TBHQ concentration which could be used for the reduction of oxydation effects during refining process was $50 \mathrm{ppm}$. Due to the antioxidant loss during refining process, antioxidant addition should be performed to refined oil for stability improvement during storage.

KEYWORDS: Antioxidant, fish oil, sardine oil.

\section{PENDAHULUAN}

Minyak ikan merupakan jenis minyak yang memiliki kandungan asam lemak tak jenuh paling tinggi dibandingkan dengan jenis minyak lainnya.

) Peneliti pada Instalasi Penclitian Perikanan Laut Slipi, Jakarta 
Ditinjau dari segi kesehatan, hal ini sangat menguntungkan terutama kandungan asam lemak omega-3 nya. Kandungan asam lemak tak jenuh yang tinggi menyebabkan minyak ikan menjadi kurang stabil, karena mudah mengalami oksidasi. Proses oksidasi akan semakin meningkat dengan adanya panas, cahaya dan oksigen.

Hampir semua tahapan pada pemurnian minyak ikan melibatkan panas dan dilakukan pada tempat yang memungkinkan kontak langsung dengan udara. Tahapan tersebut adalah degumming, netralisasi, pemucatan dan deodorisasi.

Hipotesa yang diuji dalam penelitian ini adalah bahw̧wa kerusakan minyak ikan akibat oksidasi selama proses pemurnian dapat dikurangi dengan penambahan antioksidan dan setiap jenis antioksidan mempunyai tingkat efektivitas kerja yang berbeda-beda. Penggunaan antioksidan, termasuk jenis dan konsentrasinya, harus sesuai dengan persyaratan yang ditetapkan oleh Departemen Kesehatan Republik Indonesia (1988). Jenis antioksidan yang diteliti adalah yang sering digunakan di Indonesia, sehingga memudahkan dalam penerapannya.

Bila oksidasi dapat dicegah atau dikurangi dengan menggunakan antioksidan yang tepat, proses pemurnian diharapkan dapat menghasilkan minyak ikan bermutu baik dengan kandungan asam lemak tak jenuh yang tinggi. Usaha pemanfaatan minyak ikan yang mempertimbangkan keunggulankeunggulan yang dimilikinya, terutama kandungan asam lemak omega-3, akan sangat bermanfaat, karena dapat menghasilkan produk sesuai dengan yang diinginkan.

\section{BAHAN DAN METODE}

\section{Bahan}

Minyak lemuru yang digunakan dalam penelitian ini adalah merupakan limbah dari kegiatan penepungan yang diperoleh dari pengumpul minyak ikan di Muncar, Banyuwangi. Minyak tersebut dibawa ke Instalasi Penelitian Perikanan Laut Slipi dengan wadah jerigen plastik. Pengambilan dilakukan dua kali, yaitu pertama untuk penelitian Seleksi Antioksidan dan kedua untuk penelitian Penentuan Konsentrasi Optimum Antioksidan Pada Pemurnian.

\section{Metode Penelitian}

Penelitian dilaksanakan dalam dua tahap, yaitu penelitian pendahuluan dan penelitian utama.

Pada penelitian pendahuluan dilakukan seleksi jenis antioksidan yang paling sesuai untuk melindungi minyak ikan lemuru dari proses oksidasi. Jenis antioksidan yang digunakan adalah BHA (Butylated Hidroxyanisole), BHT (Butylated Hidroxytoluene), PG (Propyl Gallate) dan TBHQ (Tert Butyl 
Hydroxyquinone) yang masing-masing ditambahkan sebanyak 200 ppm yang merupakan konsentrasi maksimum yang diijinkan oleh Departemen Kesehatan RI (1988) serta antioksidan tokoferol yang ditambahkan pada konsentrasi 1000 ppm (Irianto, 1992). Antioksidan tersebut dilarutkan ke dalam minyak ikan dengan konsentrasi masing-masing $20 \%$ untuk keperluan pembuatan stock solution. Stock solution tersebut diberikan ke dalam minyak ikan sebelum dimurnikan. Antioksidan yang dapat memberikan perlindungan optimum terhadap minyak ikan selama pemurnian dilanjutkan pada penelitian utama.

Penelitian utama dimaksudkan untuk mendapatkan konsentrasi optimal penggunaan antioksidan pada pemurnian minyak ikan. Variasi konsentrasi antioksidan yang diamati disesuaikan dengan jenis antioksidan yang terpilih pada penelitian pendahuluan. Kemudian minyak hasil pemurnian tersebut diamati stabilitasnya dengan metoda schaal oven method, yaitu dengan menyimpan minyak di dalam oven pada suhu $\pm 62^{\circ} \mathrm{C}$ dan minyak dianalisis pada hari ke 0, 4 dan 8.

\section{Metode Pemurnizn Minyalk Ikan}

Adapun tahap-tahap proses pemurnian minyak yang dilakukan adalah sebagai berikut:

\section{Degumming}

Degumming dilakukan dengan menambahkan larutan $\mathrm{NaCl} 8 \%$ sebanyak $40 \%$ dari volume minyak yang akan dimurnikan pada suhu $70^{\circ} \mathrm{C}$ selama 15 menit.

Pemberian antioksidan pada proses pemurnian dilakukan pada proses degumming ini, yaitu pada saat minyak kasar yang dipanaskan telah mencapai suhu $70^{\circ} \mathrm{C}$. Selama penambahan dilakukan pengadukan. Antioksidan yang ditambahkan dalam bentuk stock solution $20 \%$.

\section{b. Netralisasi}

Minyak yang telah mengalami proses degumming ditambah $\mathrm{NaOH}$ sesuai kandungan asam lemak bebasnya (ALB). Diaduk pada suhu $70^{\circ} \mathrm{C}$ selama 30 menit atau sampai sabun yang terbentuk menggumpal, kemudian didiamkan selama $15 \mathrm{jam}$. Selanjutnya sabun dipisahkan dengan memusingnya pada suhu $20^{\circ} \mathrm{C}$, selama 15 menit dengan kecepatan $10.000 \mathrm{rpm}$. Untuk menghilangkan sisa-sisa sabun ditambah dengan air hangat dan selanjutnya dipusing kembali untuk memisahkan minyak dari air dan sisa sabun.

\section{c. Pemucatan (Bleacbing)}

Pemucatan dilakukan dengan penambahan bentonit sebanyak $6 \%$ pada suhu $60^{\circ} \mathrm{C}$ dan kemudian diaduk selama 20 menit.

Untuk memisahkan bentonit, minyak yang telah dipucatkan dipusing selama 15 menit pada kecepatan $10.000 \mathrm{rpm}$ dan suhu $20^{\circ} \mathrm{C}$. 


\section{Analisis}

Minyak yang dihasilkan dari pemurnian tersebut kemudian dianalisis untuk mengetahui bilangan peroksida (Fardiaz et al., 1989), bilangan asam tiobarbiturat/TBA (Li dan Regenstein, 1990), kandungan asam lemak bebas/ALB (Fernandez, 1986) dan nilai absorbansi (dengan Spektronik 21 pada panjang gelombang $490 \mathrm{~nm}$ ). Penelitian dilakukan dengan 3 kali ulangan.

Pada data yang diperoleh dilakukan analisis sidik ragam dan bila perlakuan menunjukkan pengaruh nyata dilakukan uji lanjut Tukey atau Dunnet.

\section{HASIL DAN PEMBAHASAN}

\section{Seleksi Antioksidan}

Bahan mentah yang digunakan untuk penelitian seleksi antioksidan mempunyai kandungan ALB 3,20\% (asam oleat), bilangan peroksida $11,76 \mathrm{meq} / \mathrm{kg}$ dan nilai absorbansi 3,32 .

Hasil analisis kimia dan fisika minyak ikan hasil pemurnian sebagai pengaruh dari penambahan berbagai jenis antioksidan dapat dilihat pada Table 1 .

Table 1. Results of chemical and physical analyses of refined fish oil

\begin{tabular}{lllll}
\hline \hline \multirow{2}{*}{ Treatment } & \multicolumn{4}{c}{ Parameter } \\
\cline { 2 - 5 } & $\begin{array}{c}\text { Peroxide } \\
\text { value } \\
(\mathrm{meq} / \mathrm{kg})\end{array}$ & $\begin{array}{c}\text { TBA value } \\
(\mathrm{mg} / \mathrm{kg})\end{array}$ & $\begin{array}{c}\text { Free Fatty } \\
\text { Acid value } \\
(\% \text { oleic acid) }\end{array}$ & $\begin{array}{c}\text { Absorbance } \\
\text { value } \\
(490 \mathrm{~nm})\end{array}$ \\
\hline Without Antioxidant & $6.0 \mathrm{~b}$ & $0.43 \mathrm{c}$ & $0.27 \mathrm{a}$ & $0.105 \mathrm{a}$ \\
Addition & & & & \\
BHA (200 ppm) & $6.3 \mathrm{c}$ & $0.27 \mathrm{~b}$ & $1.28 \mathrm{~b}$ & $0.248 \mathrm{c}$ \\
BHT (200 ppm) & $6.8 \mathrm{~d}$ & $0.21 \mathrm{ab}$ & $1.28 \mathrm{~b}$ & $0.263 \mathrm{c}$ \\
PG (200 ppm) & $5.7 \mathrm{~b}$ & $0.15 \mathrm{a}$ & $0.93 \mathrm{~b}$ & $0.195 \mathrm{~b}$ \\
Tocopherol $(1000 \mathrm{ppm})$ & $6.3 \mathrm{c}$ & $0.15 \mathrm{a}$ & $0.97 \mathrm{~b}$ & $0.264 \mathrm{c}$ \\
TBHQ $(200 \mathrm{ppm})$ & $2.3 \mathrm{a}$ & $0.14 \mathrm{a}$ & $0.16 \mathrm{a}$ & $0.171 \mathrm{~b}$ \\
\hline \hline
\end{tabular}

Note: values followed with the same characters show insignificant different according to Tukey test

Seleksi jenis antioksidan yang efektif terutama didasarkan pada hasil analisis bilangan peroksida dan bilangan TBA. Hasil analisis sidik ragam menunjukkan bahwa jenis antioksidan berpengaruh sangat nyata terhadap bilangan peroksida dan bilangan TBA. Uji lanjut Tukey menyatakan bahwa penggunaan antioksidan TBHQ pada pemurnian minyak ikan secara nyata dapat menghasilkan minyak murni dengan bilangan peroksida yang lebih rendah dibandingkan dengan penggunaan antioksidan yang lain. 
Uji lanjut Tukey terhadap bilangan TBA menyatakan bahwa penggunaan antioksidan TBHQ menghasilkan minyak murni dengan bilangan TBA yang tidak berbeda nyata dengan penggunaan antioksidan PG dan tokoferol, tetapi secara nyata lebih rendah dibandingkan dengan penggunaan BHT dan BHA. Bilangan TBA diperoleh dengan mengukur jumlah malonaldehid yang merupakan produk antara (intermediate products) yang terbentuk selama proses oksidasi.

Ditinjau dari kemampuan antioksidan dalam menghambat pembentukan hidroperoksida dan malonaldehid, ternyata TBHQ lebih efektif digunakan untuk menghambat kerusakan minyak ikan akibat oksidasi selama proses pemurnian dibandingkan antioksidan lainnya.

Jenis antioksidan yang digunakan juga menunjukkan pengaruh yang sangat nyata terhadap kandungan asam lemak bebas (ALB) dan nilai absorbansi dari minyak ikan. Penambahan BHA, BHT, PG dan tokoferol pada pemurnian menghasilkan minyak ikan dengan kandungan asam lemak bebas lebih tinggi dibandingkan dengan minyak ikan yang ditambah TBHQ dan yang tanpa ditambah antioksidan. Dari hasil tersebut dapat diduga bahwa BHA, BHT, PG dan tokoferol kemungkinan dapat menghambat jalannya reaksi pada proses netralisasi.

Uji Tukey memperlihatkan bahwa penggunaan antioksidan PG dan TBHQ menghasilkan minyak ikan murni dengan nilai absorbansi yang lebih rendah dibandingkan dengan penggunaan antioksidan lainnya. Dengan demikian penggunaan kedua jenis antioksidan dapat menghasilkan minyak ikan dengan
warna yang jernih.

Dari hasil di atas maka diputuskan untuk menggunakan antioksidan TBHQ dalam penelitian selanjutnya.

\section{Efektivitas Penggunaan TBHQ Pada Pemurnian Minyak Ikan}

Minyak ikan yang digunakan dalam penelitian ini mempunyai kandungan asam lemak bebas $3,13 \%$ (asam oleat), bilangan peroksida $3,4 \mathrm{meq} / \mathrm{kg}$, bilangan TBA $2,1 \mathrm{mg} / \mathrm{kg}$ dan nilai absorbansi 3,63 .

Untuk melihat efektivitas antioksidan TBHQ dalam menekan terjadinya oksidasi selama pemurnian minyak ikan, dapat dilihat dari hasil analisis minyak ikan sebelum dan sesudah dimurnikan yang disajikan pada Table 2.

Penambahan antioksidan dapat menekan pembentukan hidroperoksida selama proses pemurnian, karena bilangan peroksida dari minyak yang ditambah dengan antioksidan (50-200 ppm) tidak menunjukkan perbedaan yang nyata dengan bilangan peroksida minyak yang belum dimurnikan. Sedangkan minyak ikan yang dimurnikan tanpa penambahan antioksidan menunjukkan kenaikan bilangan peroksida, walaupun kenaikannya tidak besar. Kenaikan 
yang tidak besar diduga akibat terjadinya proses dekomposisi hidroperoksida menjadi produk-produk sekunder oksidasi, karena pada suhu yang tinggi proses pembentukan dan dekomposisi dari hidroperoksida berlangsung dengan cepat (Hiatt dan Irwin, 1968; Nawar, 1985). Tampaknya pemberian antioksidan 50 ppm telah cukup untuk menekan pembentukan hidroperoksida selama pemurnian minyak ikan.

Table 2. Results of chemical analysis of refined fish oil with TBHQ addition at various concentration

\begin{tabular}{|c|c|c|c|c|}
\hline \multirow{2}{*}{$\begin{array}{c}T B H Q \\
\text { concentration }\end{array}$} & \multicolumn{3}{|c|}{ Parameter } & \multirow[b]{2}{*}{$\begin{array}{c}\text { Absorbance } \\
\text { value } \\
(490 \mathrm{~nm})\end{array}$} \\
\hline & $\begin{array}{l}\text { Peroxide } \\
\text { value } \\
\text { (meq/kg) }\end{array}$ & $\begin{array}{c}\text { TBA value } \\
(\mathrm{mg} / \mathrm{kg})\end{array}$ & $\begin{array}{c}\text { Free Fatty } \\
\text { Acid value } \\
(\% \text { oleic acid })\end{array}$ & \\
\hline oppm & $4.3 b$ & $2.7 c$ & $0.29 a$ & $0.122 a$ \\
\hline $50 p p m$ & $3.8 a$ & $2.0 \mathrm{~b}$ & $0.24 a$ & $0.176 a$ \\
\hline $100 \mathrm{ppm}$ & $3.4 a$ & $1.5 a$ & $0.23 a$ & $0.166 a$ \\
\hline 150 ppm & $3.6 a$ & $1.5 a$ & $0.25 a$ & $0.182 a$ \\
\hline $200 \mathrm{ppm}$ & $3.8 a$ & $1.4 a$ & $0.24 a$ & $0.176 a$ \\
\hline Crude oil & $3.4 a$ & $2.1 b$ & $3.42 b$ & $3.625 b$ \\
\hline
\end{tabular}

Note: values followed with the same characters show insignificant different according to Tukey test

Minyak ikan yang ditambah dengan antioksidan cenderung mempunyai bilangan TBA yang lebih rendah, dibandingkan dengan minyak yang tanpa ditambah antioksidan dan hal ini menunjukkan bahwa jumlah malonaldehid yang terbentuk lebih kecil. Terbatasnya jumlah malonaldehid yang terbentuk diduga akibat jumlah hidroperoksida tersedia yang akan diubah menjadi malonaldehid juga terbatas. Kejadian sebaliknya ditemui pada minyak ikan yang dimurnikan tanpa penambahan antioksidan. Reaksi terbentuknya malonaldehid dari hidroperoksida telah diuraikan oleh Erickson dan Bowers (1976).

Penambahan antioksidan tidak menyebabkan gangguan terhadap proses netralisasi dan pemucatan. Hal ini ditunjukkan oleh kenyataan bahwa minyak ikan yang telah dimurnikan, baik yang ditambah dengan antioksidan maupun tidak, mempunyai kandungan ALB dan nilai absorbansi yang tidak berbeda nyata.

\section{Uji Stabilitas Minyak Ikan}

Uji stabilitas terhadap minyak ikan yang telah dimurnikan dimaksudkan untuk melihat sampai sejauh mana pengaruh dari antioksidan yang telah ditambahkan pada saat pemurnian terhadap stabilitas minyak ikan pasca pemurnian. Dari hasil penelitian diharapkan diperoleh informasi apakah antioksidan yang ditambahkan pada saat pemurnian masih mampu mempertahankan stabilitas minyak ikan selama penyimpanan atau mungkin diperlukan 
adanya penambahan anti-oksidan lagi untuk meningkatkan stabilitasnya. Seperti halnya antioksidan alami yang terdapat pada minyak ikan, kemungkinan sebagian antioksidan yang ditambahkan juga ada yang hilang selama pemurnian, sehingga antioksidan TBHQ yang tersisa tidak dapat dengan baik melindungi minyak ikan dari proses oksidasi.

\section{Bilangan Peroksida dan TBA}

Perlakuan penambahan antioksidan memberikan pengaruh yang sangat nyata terhadap bilangan peroksida dari minyak ikan yang dihasilkan. Semakin tinggi jumlah antioksidan yang ditambahkan selama pemurnian menyebabkan bilangan peroksida minyak ikan selama penyimpanan semakin rendah (Figure 1). Berdasarkan uji lanjut Dunnet diperoleh informasi bahwa bilangan peroksida minyak ikan yang ditambah antioksidan sebanyak 100, 150 dan 200 ppm tidak berbeda nyata dengan bilangan peroksida minyak yang tidak dimurnikan. Dengan demikian penambahan antioksidan pada tingkat konsentrasi tersebut dapat menggantikan fungsi antioksidan alami minyak ikan yang hilang karena proses pemurnian.

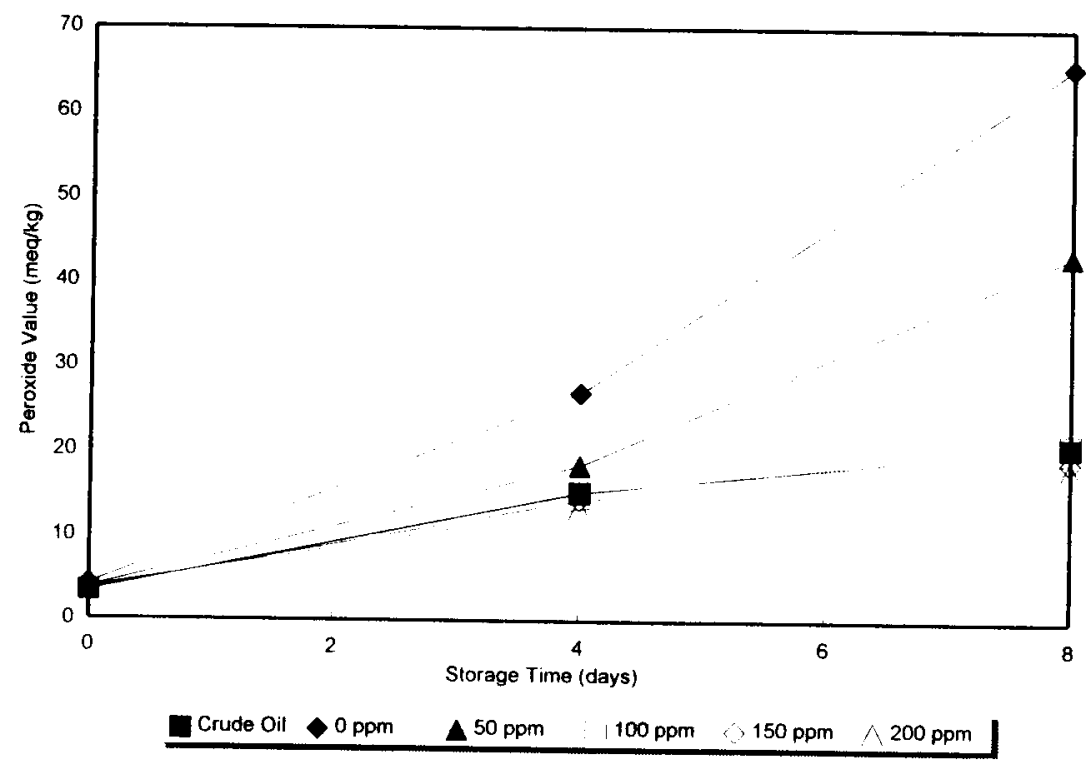

Figure 1. Peroxide values of fish oil during stability test

Bilangan peroksida pada semua minyak ikan yang diteliti cenderung meningkat selama uji stabilitas. Peningkatan bilangan peroksida menunjukkan adanya proses oksidasi, walaupun pada minyak telah ditambah antioksidan. Peroksida terbentuk pada tahap propagasi dari proses oksidasi (Gunstone and Norris, 1983). 
Uji sidik ragam menunjukkan bahwa perlakuan penambahan antioksidan berpengaruh nyata terhadap bilangan TBA minyak ikan yang telah dimurnikan selama uji stabilitas. Penambahan antioksidan pada konsentrasi 100, 150 dan 200 ppm pada pemurnian dapat menghambat laju pembentukan malonaldehid pada minyak ikan selama penyimpanan (Figure 2). Walaupun demikian peningkatan laju pembentukan malonaldehid tersebut lebih tinggi dibandingkan dengan yang terjadi pada minyak ikan yang belum dimurnikan. Diduga TBHQ yang tersisa tidak cukup untuk menghambat dekomposisi hidroperoksida menjadi malonaldehid.

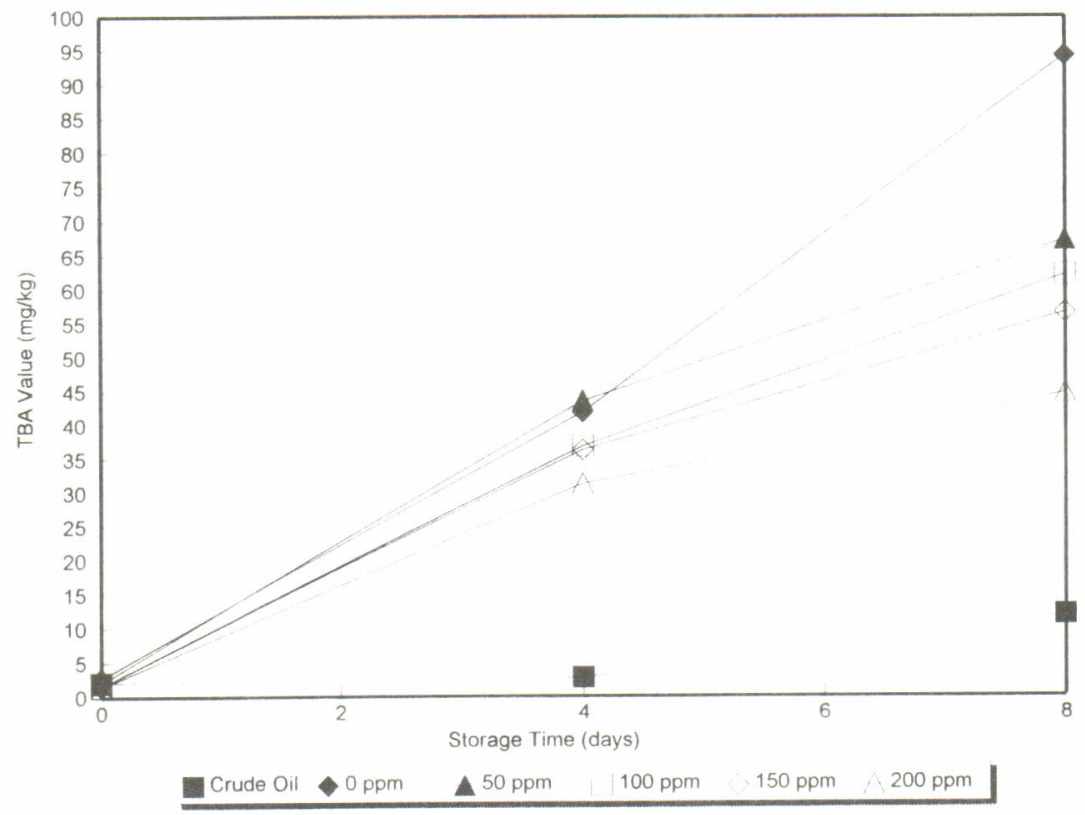

Figure 2. TBA values of fish oil during stability test

\section{b. Kandungan Asam Lemak Bebas (ALB)}

Analisis sidik ragam nenunjukkan bahwa perlakuan penambahan antioksidan berpengaruh nyata terhadap kandungan ALB minyak ikan selama penyimpanan. Penambahan antioksidan TBHQ menyebabkan minyak ikan mempunyai kandungan ALB yang lebih rendah dibandingkan dengan minyak ikan yang tidak ditambah antioksidan. Uji Tukey memperlihatkan bahwa penambahan antioksidan (50-200 ppm) tidak menyebabkan perbedaan yang nyata terhadap kandungan ALB minyak ikan selama uji stabilitas. Penyimpanan menyebabkan penurunan kandungan ALB (Table 3). Penurunan tersebut kemungkinan disebabkan oleh proses oksidasi terhadap asam lemak bebas yang di antaranya menghasilkan senyawa mudah menguap, seperti alkohol (Muchtadi et al., 1992). 
Table 3. Free fatty acid contents of fish oil during stability test (\% oleic acid)

\begin{tabular}{cccc}
\hline \hline \multirow{3}{*}{$\begin{array}{c}\text { TBHQ } \\
\text { Concentration }\end{array}$} & \multicolumn{3}{c}{ Storage time (days) } \\
\cline { 2 - 4 } & 0 & 4 & 8 \\
\hline $0 \mathrm{ppm}$ & 0.29 & 0.21 & 0.17 \\
$50 \mathrm{ppm}$ & 0.24 & 0.20 & 0.11 \\
$100 \mathrm{ppm}$ & 0.23 & 0.16 & 0.11 \\
$150 \mathrm{ppm}$ & 0.25 & 0.18 & 0.11 \\
$200 \mathrm{ppm}$ & 0.24 & 0.18 & 0.12 \\
Crude oil & 3.13 & 3.42 & 2.90 \\
\hline \hline
\end{tabular}

\section{c. Nilai Absorbansi}

Berdasarkan hasil analisis sidik ragam diperoleh bahwa nilai absorbansi secara nyata dipengaruhi oleh penambahan antioksidan. Minyak murni yang ditambah antioksidan pada saat pemurnian mempunyai nilai absorbansi yang lebih tinggi dibandingkan dengan minyak yang tidak ditambah antioksidan selama uji stabilitas. Uji Tukey memperlihatkan bahwa penambahan antioksidan 50,100, 150 dan 200 ppm tidak menyebabkan perbedaan nyata terhadap nilai absorbansi minyak ikan. Menurut Sherwin (1990), TBHQ dapat bereaksi dengan gugus amin bebas menghasilkan warna merah dan kejadian ini kemungkinan yang menyebabkan warna minyak ikan murni yang ditambah TBHQ lebih kuning.

Nilai absorbansi minyak ikan menurun selama uji stabilitas (Table 4). Karotenoid adalah pigmen yang paling banyak terkandung dalam minyak ikan

Table 4. Absorbance values of fish oil during stability test $(490 \mathrm{~nm})$

\begin{tabular}{cccc}
\hline \multirow{2}{*}{$\begin{array}{c}\text { TBHQ } \\
\text { Concentration }\end{array}$} & \multicolumn{3}{c}{ Storage time (days) } \\
\cline { 2 - 4 } & 0 & 4 & 8 \\
\hline $0 \mathrm{ppm}$ & 0.122 & 0.108 & 0.073 \\
$50 \mathrm{ppm}$ & 0.176 & 0.156 & 0.114 \\
$100 \mathrm{ppm}$ & 0.166 & 0.142 & 0.076 \\
$150 \mathrm{ppm}$ & 0.182 & 0.167 & 0.119 \\
$200 \mathrm{ppm}$ & 0.176 & 0.161 & 0.105 \\
Crude oil & 3.625 & 3.124 & 2.902 \\
\hline \hline
\end{tabular}


(Brody, 1965). Dekomposisi karotenoid menyebabkan memudarnya warna produk (Emodi, 1978). Bagian tidak jenuh dari karotenoid mudah dipengaruhi oleh oksigen (Stuckey, 1972) yang menyebabkan peristiwa oksidasi dan menghasilkan produk dengan warna yang pucat, sehingga nilai absorbansinya menurun.

\section{Konsentrasi Optimum Penambahan TBHQ}

Hasil penelitian menunjukkan bahwa penggunaan TBHQ untuk menghambat proses oksidasi pada minyak ikan selama pemurnian ternyata cukup efektif. Keunggulan TBHQ dalam melindungi produk pangan telah dibuktikan oleh Ke et al. (1977) pada lipid kulit ikan kembung serta Tokarska et al. (1986) dan Hawrysh et al. (1988; 1989) pada minyak Canola.

Dalam penelitian ini penambahan TBHQ tidak hanya dimaksudkan untuk mempertahankan stabilitas minyak ikan selama pemurnian, tetapi diharapkan juga masih menunjukkan aktivitasnya selama penyimpanan. Penambahan TBHQ sebanyak 50 ppm telah cukup untuk melindungi minyak ikan selama proses pemurnian, tetapi untuk menjaga stabilitas minyak ikan pasca pemurnian belum mencukupi. Pemurnian dengan penambahan TBHQ sebanyak 100 ppm menghasilkan minyak ikan yang selama penyimpanan mempunyai bilangan peroksida yang setara dengan minyak ikan yang belum dimurnikan, tetapi laju peningkatan bilangan TBA nya jauh lebih besar.

Hal tersebut menunjukkan bahwa kemungkinan selama proses pemurnian terjadi kehilangan TBHQ. TBHQ yang tersisa hanya cukup untuk menghambat proses pembentukan peroksida, tetapi tidak cukup untuk menghambat proses dekomposisi peroksida menjadi malonaldehid. Dengan demikian penambahan antioksidan pada saat pemurnian tidak cukup untuk mempertahankan stabilitas minyak ikan pasca pemurnian. Maka untuk mendapatkan stabilitas yang baik pada minyak ikan yang telah dimurnikan sebaiknya dilakukan penambahan antioksidan lagi.

Hasil analisis penentuan nilai absorbansi menunjukkan bahwa pada tingkat penambahan TBHQ $100 \mathrm{ppm}$ telah cukup untuk menghindarkan memudarnya warna minyak ikan lemuru selama penyimpanan. Diduga pencegahan proses dekomposisi karotenoid tidak memerlukan jumlah antioksidan yang banyak, sehingga sisa TBHQ dan antioksidan alami telah cukup untuk mempertahankan warna dari minyak.

\section{KESIMPULAN}

TBHQ merupakan antioksidan yang paling efektif digunakan untuk mencegah terjadinya oksidasi pada minyak ikan lemuru selama pemurnian dan ini ditunjukkan dengan penekanan bilangan peroksida dan bilangan TBA dari minyak murni. Penambahan TBHQ sebanyak $50 \mathrm{ppm}$ selama pemurnian telah 
cukup untuk menggantikan sejumlah antioksidan alami yang hilang, tetapi bila akan dilakukan penyimpanan terhadap minyak ikan yang telah dimurnikan perlu dilakukan penambahan lagi, karena diduga proses pemurnian juga menyebabkan kehilangan sebagian TBHQ yang ditambahkan.

\section{DAFTAR PUSTAKA}

Brody. 1965. Fishery by-products technology, The AVI publishing Co. Ltd., Westport, Connecticut

Departemen Kesehatan RI. 1988. Peraturan Menteri Kesehatan Republik Indonesia No.722/Menkes/Per/IX/88 Tentang Bahan Tambahan Makanan, Dep. Kes. RI, Jakarta

Emodi, A. 1978. Carotenoids, properties and applications, Food.Tech. 32 (5): 38-48

Erickson, D.R. dan Bowers, R.H. 1976. Objective determination of fat stability in prepared foods, dalam Objective methods for food evaluation: Proceedings of a symposium, 133-144, National Academy of Science, Washington D.C.

Fardiaz, D., A. Apriyantono, N.L. Puspitasari, Sedarnawati dan S. Budiyanto. 1989. Analisa pangan, PAU Pangan dan Gizi, IPB, Bogor

Fernandez, C.C. 1986. Refinement of fish oil for human consumption: engineering investigation, Disertasi PhD, University of Washington, Seattle

Gunstone, F.D. dan F.A.Norris. 1983. Lipids in foods: chemistry, biochemistry and technology, Pergamon Press Ltd., Oxford

Hawrysh, Z.J., P.J. Shand, B. Tokarska dan C. Lin. 1988. Effects of tertiary butylhydroquinone on storage stability of canola oil. I. Accelerated storage, Can.Inst.Food.Sci.Technol.J. 21 (5): 549-554

Hawrysh, Z.J., P.J. Shand, B. Tokarska dan C. Lin. 1989. Effects of tertiary butylhydroquinone on storage stability of canola oil. II. Practical storage, Can.Inst.Food.Sci.Technol.J. 22 : 40-45

Hiatt, R. dan K.C.Irwin. 1968. Homolytic decomposition of hydroperoxide. V. Thermal decomposition, J.Org.Chem. 33: 1436-1441

Irianto, H.E. 1992. Fish oil: refining, stability and its use in canned fish for the Indonesian market, Disertasi PhD, Massey University, New Zealand

Ke, P.J., D.M.Nash dan R.G.Ackman. 1977. Mackerel skin lipids as an unsaturated fat model system for the determination of antioxidative potency of TBHQ and other antioxidant compounds, JAOCS 54 (10): 417-420 
Li, Y.T. dan J.M.Regenstein. 1990. Use of Menhaden fish oil in mayonnaise, dalam Advances in fisheries technology and biotechnology for increased profitability, M.N.Voigt dan J.R.Botta (Ed.), Technomic Publishing Co.Inc., Lancaster, p.151-161

Muchtadi, D., N.S. Palupi dan M.Astawan. 1992. Metoda kimia biokimia dan biologi dalam evaluasi nilai gizi pangan olahan, PAU Pangan dan Gizi, IPB, Bogor

Nawar, W.W. 1985. Thermal and radiolytic decomposition of lipids, dalam Chemical changes in food during processing, edited by T.Richardson dan J.W.Finley, The AVI publishing Co.Inc., Westport, Connecticut, p.79-105

Sherwin, E.R. 1990. Antioxidants, dalam Food additives, A.L.Branen, P.M. Davidson dan S.Salminen (Ed.), Marcel Dekker Inc., New York, p.139-193

Stuckey, B.N. 1972. Antioxidants as food stabilizers, dalam CRC handbook of food additives, T.E.Furia (ed.), CRC Press, Florida

Tokarska, B., Z.J.Hawrysh dan M.T.Claudinin. 1986. Study of the effect of antioxidants on storage stability of canola oil using gas liquid chromatography, Can.Ins.Food.Scie.Tech. 19 (3): 130-133 